\title{
Osebnostne lastnosti psov in njihovih lastnikov
}

\author{
Nuša Klinar ${ }^{1}$ in Andreja Avsec ${ }^{2}$ \\ ${ }^{1}$ Jesenice \\ ${ }^{2}$ Oddelek za psihologijo, Filozofska fakulteta Univerze v Ljubljani
}

\begin{abstract}
Povzetek: V raziskavi nas je zanimala povezanost samoocen osebnostnih lastnosti lastnikov z njihovimi ocenami osebnostnih lastnosti njihovih psov ter razlike med psi različnih pasem v osebnostnih lastnostih. V raziskavi je sodelovalo 661 lastnikov (556 žensk in 105 moških) ter enako število njihovih psov (332 samic in 329 samcev). Udeleženci so izpolnili vprašalnik velikih petih faktorjev osebnosti BFI ter preko prirejenega vprašalnika velikih pet BFI ocenili osebnostne lastnosti svojih psov. Ugotovili smo pomembno povezanost med vsemi dimenzijami lastnikove osebnosti in osebnostnimi lastnostmi njihovih psov. Poleg možnega vplivanja lastnika s svojimi lastnostmi na lastnosti psa je možen vzrok visokih korelacij tudi napaka ocenjevanja psov s strani lastnikov, saj si le-ti lahko želijo, da so jim psi v določenih značilnostih podobni. Ugotovili smo tudi, da se psi različnih pasem razlikujejo glede na izraženost treh od štirih ocenjenih osebnostnih lastnosti. V določeni meri so te razlike med pasmami skladne $\mathrm{z}$ opisi, ki jih podajajo vzreditelji, pogosto pa vzreditelji podajajo tako pomanjkljive opise, da ne moremo preveriti njihove skladnosti z našimi rezultati. Kljub temu, da raziskave na splošno kažejo, da so lastniki dobri ocenjevalci lastnosti svojih psov, je zaradi teoretičnih in praktičnih problemov merjenja osebnostnih lastnosti pri psih potrebno biti previden pri interpretaciji dobljenih rezultatov.
\end{abstract}

Ključne besede: osebnostne lastnosti, psi, razlike med vrstami

\section{Personality of owners and their dogs}

\author{
Nuša Klinar ${ }^{1}$ and Andreja Avsec ${ }^{2}$ \\ ${ }^{1}$ Jesenice, Slovenia \\ ${ }^{2}$ Department of Psychology, Faculty of Arts, University of Ljubljana, Slovenia
}

\begin{abstract}
The aim of our study was to find association between the personality of owners and the personality of their dogs, assessed by their owners. Furthermore, we were interested in finding differences between dogs of different breeds. The sample included 661 owners (556 women and 105 men) and an equal number of their dogs (332 females and 329 males). The participants filled in the Big Five Inventory and slightly adopted the Big Five Inventory for dogs. The results indicated statistically significant correlations between almost all owner's personality dimensions and personality dimensions of their dogs. Besides the influence of owners and their personalities on the dog's personality, a possible cause of these associations could be their misevaluation as they want their dogs to have some equal characteristics as they have. Analysis of the data also revealed significant differences in dimensions between breeds in three of four dogs' personalities. Results were partly in accordance with hypothesized differences which were based upon official descriptions of temperament of specific breeds. Despite the fact that the research confirms that owners can judge dog's personality with satisfactory levels of accuracy, it is necessary to account all limitations of measuring dogs' personality in interpreting the results.
\end{abstract}

Keywords: personality traits, dogs, species differences

\footnotetext{
${ }^{*}$ Naslov/Address: izr. prof. dr. Andreja Avsec, Oddelek za psihologijo, Filozofska fakulteta Univerze v Ljubljani, Aškerčeva 2, 1000 Ljubljana; e-mail: andreja.avsec@psiha.net
}

Članek je licenciran pod pogoji Creative Commons Attribution 4.0 International licence. (CC-BY licenca).

The article is licensed under a Creative Commons Attribution 4.0 International License (CC-BY license). 
Raziskovanje osebnosti živali se kljub spodbudnim začetkom v prvi polovici 20. stoletja (Jones in Gosling, 2005) kasneje ni razvijalo hitro. Šele proti koncu 20. stoletja so se raziskovalci bolj podrobno začeli ukvarjati z vprašanji temperamenta pri psih ter njegovega vpliva na obnašanje in odzivanja na okolje (Jones in Gosling, 2005). Čeprav nimamo splošno sprejete taksonomije osebnostnih lastnosti pri živalih, pa danes raziskave kažejo, da osebnost pri živalih obstaja in da jo lahko merimo (npr. Gosling, Kwan in John, 2003; Gosling in Vazire, 2002).

Tako kot na področju razvojne psihologije, se tudi na področju živalske psihologije pojavljajo nasprotujoča mnenja o razvoju in oblikovanju osebnostnih lastnosti ter vplivih nanje (Podberscek in Gosling, 2000; Podberscek in Serpell, 1997). Do poznih 70. let je bilo med trenerji psov razširjeno mnenje, da je večina težav v vedenju psov rezultat lastnikove pomanjkljive avtoritete, discipline ali nadzora nad njihovimi domačimi živalmi. Kasneje pa so začeli poudarjati tudi vpliv genetskih dejavnikov na vedenje psa ter idejo o odgovornosti lastnikov za vedenje živali označili kot zavajajočo (Mugford, 1995). Zato nas je $\mathrm{v}$ naši raziskavi zanimala povezanost med osebnostnimi lastnostmi lastnikov in osebnostnimi lastnostmi psov, pri čemer je ključno vprašanje, ali osebnostne lastnosti, ki jih ocenimo z vprašalniki, odražajo resnične značilnosti posameznega psa?

Gosling in Vazire (2002) predlagata, da raziskovalci osebnosti pri živalih upoštevajo iste glavne kriterije, ki sta jih Kenrick in Funder (1988) izpostavila kot temeljne za dokazovanje obstoja osebnostnih lastnosti pri ljudeh:

a) soglasje med ocenami neodvisnih opazovalcev;

b) ocene morajo napovedovati vedenje $\mathrm{v}$ resničnih situacijah in

c) ocene opazovalcev morajo odražati resnične lastnosti ocenjevanih posameznikov in ne le opazovalčevih implicitnih osebnostnih teorij.

Eden izmed problemov, ki se pojavlja pri preučevanju osebnostnih lastnosti pri psih, je pomanjkanje splošno sprejete taksonomije osebnostnih lastnosti. Za organiziranje osebnostnih lastnosti pri psih bi lahko uporabili leksični pristop, vendar uporaba petfaktorskega modela osebnosti pri živalih ter predvidevanje, da imajo psi enake osebnostne lastnosti kot ljudje, ni enotno podprta med raziskovalci (Lay in Bennett, 2007). Pri uporabi vprašalnikov velikih pet so namreč lahko nekatere osebnostne lastnosti (npr. poslušnost) izpuščene ali napačno interpretirane, prav tako pri psih še ni dokazan obstoj dimenzije vestnosti, ki je morda odvisna od višjih stopenj kognitivnih sposobnosti (Lay in Bennet, 2007). Kot neodvisna dimenzija osebnosti se je lahko pojavila relativno pozno $\mathrm{v}$ evolucijski zgodovini, dolgo potem, ko so se predniki psov, kanidi, začeli oddaljevati od prednikov človeka, saj so obstoj medosebnih razlik v vestnosti dokazali le pri človeku in šimpanzih (Gosling idr., 2003). Ena izmed raziskav na tem področju (Jones in Gosling, 2005) na primer ugotavlja, da je za kategoriziranje osebnostnih lastnosti pri psih bolj primeren sedemdimenzijski model osebnosti (reaktivnost, bojazljivost, aktivnost, družabnost, odzivnost na trening, podredljivost, agresivnost). Kubinyi, Turcsán in Miklósi (2009) so na podlagi ocen 14,000 psov na 24 postavkah predlagali štiri osebnostne lastnosti: mirnost, učljivost, družabnost in pogum. Ley, Bennett in Coleman (2008) pa so predlagali pet lastnosti na podlagi 67 postavk: ekstravertnost, samozavest/motivacija, usmerjenost na učenje, prisrčnost in nevroticizem. Spet druga raziskava (Mirkó, Kubinyi, Gácsi in Miklósipa, 2012) pa je predlagala naslednje lastnosti: družabnost do tujcev, aktivnost, agresivnost in učljivost. Kot vidimo iz preteklih raziskav, trenutno še ni enotnega pogleda na strukturo osebnosti pri psih.

$\mathrm{Na}$ področju ocenjevanja osebnosti pri živalih je pomembno tudi razlikovanje med znotrajvrstnim ali znotrajpasemskim in medvrstnim ali medpasemskim primerjanjem; vrsta primerjave lahko namreč močno spremeni njen pomen (Gosling, 2001). Na primer, ko posameznik nemškega ovčarja oceni na dimenziji nevroticizma, je pomembno, ali mu je oceno podal na podlagi primerjave $z$ drugimi psi v splošnem ali na podlagi primerjave $\mathrm{z}$ ostalimi nemškimi ovčarji (Podberscek in Gosling, 2000). Pomembno vprašanje pri medpasemskih primerjavah je tudi, ali ocena psa predstavlja značilnosti psa, značilnosti posameznika, ki psa ocenjuje, ali odnos med ocenjevalcem in psom. Verjetno je ocena sestavljena iz vseh treh omenjenih komponent (Gosling, 1998): del ocene odraža resnično vedenje psa, del ocene odraža zaznavne in pojmovne sposobnosti ocenjevalca, del ocene pa odraža vidike odnosa med ocenjevalcem in psom. Omenjene omejitve pri ocenjevanju osebnosti pri živalih pa še ne pomenijo, da so ocene brez pomena, pač pa da se raziskovalci morajo zavedati, kaj vse lahko odražajo njihovi podatki (Podberscek in Gosling, 2000).

Ali lastnikova osebnost lahko vpliva na osebnostne lastnosti in posledično na vedenje živali, je pogosto predmet pogovorov. Ko je Woodhouse (1978; v Jagoe in Serpell, 1996) zatrdila, da »ni slabih psov, so le slabi lastniki«, je opisala splošno sprejeto prepričanje o pomembnosti vedenja oz. osebnosti lastnikov za vedenje psov. Čeprav postaja ideja o odgovornosti lastnikov za vedenjske težave svojih živali vedno bolj sprejemljiva, pa obstaja malo raziskav, ki bi potrdile te povezave (Jagoe in Serpell, 1996). Smiselno je predvidevati, da se nekatere lastnikove osebnostne lastnosti kažejo pri psih ter tudi vplivajo na njihov osebnostni razvoj, kajti lastnik predstavlja pomembno vlogo v socialnem okolju psa (Podberscek in Gosling, 2000). O'Farrell (1995) je s pomočjo Eysenckovega osebnostnega vprašalnika proučil 50 lastnikov psov in ugotovil pogostejšo prisotnost določenih vedenjskih težav pri tistih psih, katerih lastniki so dosegli visoko število točk na dimenziji nevroticizma. Te vedenjske težave je označil kot "premestitvene učinke" in jih pripisal visokemu vzburjenju in konfliktnemu stanju, katerega povzročijo anksiozni in nevrotični lastniki. Podberscek in Serpell (1997) pa sta v raziskavi, v kateri je sodelovalo 128 lastnikov angleških koker španjelov, 
S pomočjo Catellovega 16 faktorskega vprašalnika osebnosti ugotovila, da so lastniki bolj agresivnih psov tudi bolj napeti, čustveno manj stabilni, sramežljivi in nedisciplinirani $\mathrm{v}$ primerjavi z lastniki manj agresivnih psov.

V nasprotju z idejo o odgovornosti lastnikov za vedenje živali nekateri raziskovalci živalskega vedenja zagovarjajo genetsko determiniranost in idejo, da imajo psi že prirojene predispozicije za razvoj vedenjskih težav ne glede na to, komu pripadajo (Podberscek in Serpell, 1997). Večina osebnostnih značilnosti naj bi bila tako dedno pogojenih, zato so ljudje pri vzreji pazili tudi na psihične značilnosti pasme (Coren, 1996). Za pridobitev rodovnika so zato pomembne zunanje karakteristike, dedne bolezni pa tudi osebnostne značilnosti psa, saj iz vzreje izločajo pse, ki so popadljivi, plahi ali nemirni (SKVPM, 2005). Začetek vzreje, ki se je bolj kot na prvotno funkcijo psa usmerjala na zunanji videz, sovpada z začetkom organiziranja pasjih razstav, ki se je v Angliji začela pred približno 150 leti (Lindsey, 2000). Cilji razstav so bili predvsem izbiranje in ocenjevanje psov, namenjenih za vzrejo, pri čemer so ocenjevali tako zunanjo podobo psa kot tudi karakterne značilnosti. To pomeni, da so izločili pse, ki po zunanjosti ne ustrezajo pasemskem standardu, kot tudi pse, ki so bili agresivni, pretirano plašni ali nevodljivi (Lindsey, 2000). Čeprav je v evolucijskem pogledu od začetka prirejanja pasjih razstav in s tem začetka usmerjene vzreje psov do danes preteklo malo časa, pa je smiselno predvidevati, da so se nekatere emocionalne lastnosti pri psih pod pritiskom selekcije spremenile (Svartberg, 2006). Selekcijski eksperimenti pri psih in ostalih kanidih so pokazali, da se lastnosti, povezane s strahom, pod močno selekcijo $\mathrm{v}$ nekaj generacijah hitro spreminjajo (Kenttamies idr., 2002; Trut, Plyusnina in Oskina, 2004).

Zaradi tesne povezanosti s človekom, poznavanja postopkov selektivne vzreje ter vzrejanja za določene namene, so današnji psi izredno raznoliki tako po telesnih značilnostih kot tudi po nekaterih vedenjskih značilnostih. Znotraj posamezne pasme pa so si psi zelo podobni. Pasma je skupina živali, ki so si med seboj genotipsko in fenotipsko podobne, in katerih potomci so podobne velikosti, teže, barve ter imajo podobna vedenjska nagnjena (Blood in Studdert, 1988). Razlike med pasmami so bile ugotovljene v stopnji čustvenosti in agresivnosti, v približevanju in oddaljevanju pri izpostavljenosti novim in neobičajnim situacijam, aktivnosti in igrivosti, predatorskem vedenju, ter izzivalnih znakih (Svartberg, 2006). Svartberg (2002) pa je na dimenziji poguma ugotovil tudi pomembno razliko med nemškimi ovčarji in belgijskimi tervureni.

Namen pričujoče raziskave je bil proučiti povezanost osebnostnih lastnosti lastnika z osebnostnimi lastnostmi njegovega psa. Predvidevali smo, da se lastnikove osebnostne lastnosti povezujejo z osebnostnimi lastnostmi njegovega psa, saj lastniki predstavljajo pomembno vlogo v socialnem okolju psa ter lahko s svojim vedenjem vplivajo tudi na osebnostne lastnosti psa (Podberscek in Serpell, 1997). Pričakujemo predvsem, da bo navroticizem lastnikov pozitivno povezan $\mathrm{z}$ nevroticizmom in negativno s sprejemljivostjo njihovih psov, saj naj bi njihovo nestabilno vedenje in povišana vzburjenost negativno vplivala na vedenje psov. Ker nekatere raziskave kažejo, da obstajajo razlike $\mathrm{v}$ osebnostnih značilnostih med psi različnih pasem (Svartberg, 2006) in ker je bila selektivna vzreja pasem usmerjena tudi na določene osebnostne lastnosti, pričakujemo razlike $\mathrm{v}$ osebnostnih lastnostih med različnimi pasmami, skladno z njihovimi opisi (AKC Recognized Breeds, 2013; Breed Information Centre, 2013). Namen pričujoče raziskave je bil tudi prevod ter preverjanje strukture in psihometričnih značilnosti vprašalnika osebnosti BFI za pse (Gosling idr., 2003), saj na slovenskem vzorcu še ni bil uporabljen.

\section{Metoda}

\section{Udeleženci}

$\mathrm{V}$ raziskavi je sodelovalo 661 udeležencev, 556 udeležencev je bilo ženskega spola in 105 udeležencev moškega spola. Povprečna starost udeležencev je bila 30,4 let, najmlajši udeleženec je bil star 10 in najstarejši 81 let. $54 \%$ udeležencev je bilo zaposlenih, $26 \%$ je bilo študentov, ostali pa so bili brezposelni ter upokojenci. 504 (76 \%) udeležencev je imelo v času reševanja enega psa, 106 (16 \%) udeležencev je imelo dva psa, ostali udeleženci pa so imeli več kot dva psa.

Število psov, ki so bili udeleženi v raziskavi, je bilo 661, med njimi 332 samic in 329 samcev. Povprečna starost psov je bila 5 let, pri čemer je bil najmlajši pes star 3 mesece in najstarejši 16 let. Pasemskih psov je bilo 516, 143 pa je bilo mešancev. Med vsemi psi jih je 347 (53 \%) imelo rodovnik, 394 (60 \%) psov je bilo šolanih, med katerimi jih je 191 (29\%) imelo opravljen izpit ob koncu šolanja. 117 (18 \%) psov lastniki vozijo na razstave. Med vsemi psi jih je 233 (35\%) bilo steriliziranih oziroma kastriranih.

\section{Pripomočki}

Vprašalnik osebnosti velikih pet BFI(John, Donahue in Kentle, 1991), ki meri komponente petih velikih faktorjev osebnosti, ekstravertnosti, sprejemljivosti, nevroticizma, vestnosti in odprtosti. Vprašalnik je sestavljen iz 44 postavk, pri čemer se 8 postavk nanaša na dimenzijo ekstravertnosti, 9 na sprejemljivost, 8 na nevroticizem, 10 na odprtost ter 9 na dimenzijo vestnosti. Lastniki so morali na vsaki postavki s pomočjo 5 stopenjske lestvice ( $1=$ sploh se ne strinjam; $5=$ popolnoma se strinjam) oceniti, v kolikšni meri trditev zanje velja. 12 postavk vrednotimo obrnjeno, višje število točk pa predstavlja višjo izraženost posamezne dimenzije. Alfa koeficienti notranje konsistentnosti na našem vzorcu so podobne kot jih ugotavljajo v drugih raziskavah (Avsec, 2007), in sicer od 0,74 do 0,83 .

Vprašalnik osebnosti BFI za pse (Gosling idr., 2003) so avtorji priredili iz vprašalnika BFI. Dva strokovnjaka sta preverila in priredila postavke, da so bile relevantne 
za ocenjevanje osebnosti pri psih. Končna oblika vključuje 44 postavk: 8 se jih nanaša na ekstravertnost, 8 na naklonjenost, 10 na čustveno reaktivnost, 10 na odprtost in 8 postavk na vestnost. Lastniki so morali na vsaki postavki s pomočjo 5 stopenjske lestvice $(1=$ sploh se ne strinjam; $5=$ popolnoma se strinjam) oceniti, $\mathrm{v}$ kolikšni meri trditve veljajo za njihovega psa. 12 postavk vrednotimo obrnjeno. Avtorji (Gosling idr., 2003) so na podlagi faktorske analize (v katero niso vključili postavk vestnosti) dobili štiri faktorje, ki so analogni faktorjem osebnosti pri ljudeh, in sicer energijo/ ekstravertnost, naklonjenost / sprejemljivost, čustveno reaktivnost / nevroticizem in odprtost. Pri preverjanju psihometričnih značilnosti vprašalnika, uporabljenega na slovenskem vzorcu, smo po metodi glavnih komponent $\mathrm{z}$ uporabo varimax rotacije dobili pet komponent. Rezultati analize ter ocene zanesljivosti posameznih komponent so predstavljeni na začetku poglavja Rezultati.

\section{Postopek}

Za pridobitev čim bolj raznolikega vzorca udeležencev, je zbiranje udeležencev potekalo prek spleta in prek pisnih vprašalnikov, ki so jih udeleženci dobili na veterinarski kliniki za male živali v Lescah. Pisno izpolnjene vprašalnike so udeleženci poslali po pošti raziskovalki.

\section{Rezultati}

Najprej smo preverili psihometrične značilnosti prevedenega vprašalnika BFI za pse, ki je bil na slovenskem vzorcu uporabljen prvič. Uporabili smo komponentno analizo in s testom drobirja izločili pet komponent. Nato smo uporabili Varimax rotacijo, saj se tako kot pri ljudeh teoretično predpostavlja, da so osebnostne dimenzije pri psih neodvisne, kar so pokazale tudi korelacije med faktorji, ki niso presegale vrednosti 0,30. Po varimax rotaciji so lastne vrednosti teh pet komponent in pripadajoči odstotki pojasnjene variance sledeči: 6,1 (14 \%); 4,7 (10,7 \%); 3,6 (8,2\%); 2,9 (6,6 \%) in 2,3 (5,2\%). S prvo komponento $(\alpha=0,86)$ so najbolj nasičene postavke, ki se nanašajo na ekstravertnost in odprtost, $\mathrm{z}$ drugo komponento $(\alpha=0,81)$ predvsem postavke, ki se nanašajo na nevroticizem, ki je usmerjen navzven, in nekaterimi, ki se nanašajo na sprejemljivost oz. nesprejemljivost. S tretjo komponento $(\alpha=0,74)$ so najbolj nasičene postavke vestnosti, s četrto komponento $(\alpha=0,67)$ postavke, ki se nanašajo na nevroticizem, ki je usmerjen navznoter, ter $\mathrm{s}$ peto $(\alpha=0,58)$ postavke iz različnih originalnih lestvic kot so hladen, vzvišen, muhast, svojeglav, trmast, ima prefinjen okus, samozavesten. Ker je zadnjo komponento težko vsebinsko definirati in je tudi sicer najbolj šibka in $\mathrm{z}$ nizko zanesljivostjo, jo nismo vključili v nadaljnjo statistično obdelavo. Za mere osebnostnih lastnosti psov smo v nadaljnjih statističnih analizah uporabili faktorske točke, izračunane na podlagi opisane komponentne analize in ne originalne lestvice.

Po priredbi vprašalnika smo izračunali osnovno statistiko, nato korelacije med osebnostnimi lastnostmi lastnikov in njihovih psov. Preverili smo razlike med rodovniškimi in nerodovniškimi psi v osebnostnih lastnostih ter na koncu izračunali pomembnost razlik med psi različnih pasem glede na njihove osebnostne lastnosti.

Tabela 1. Povprečne vrednosti in standardne deviacije za vprašalnik BFI za lastnike

\begin{tabular}{lrr}
\hline Osebnostna dimenzija & $M$ & $S D$ \\
\hline Ekstravertnost & 29,4 & 4,9 \\
Sprejemljivost & 33,9 & 4,9 \\
Nevroticizem & 20,7 & 5,3 \\
Odprtost & 37,7 & 5,9 \\
Vestnost & 33,8 & 5,1 \\
\hline
\end{tabular}

$\mathrm{V}$ tabeli 1 so prikazane povprečne vrednosti in standardne deviacije na vprašalniku BFI za lastnike. Za računanje povezanosti med osebnostnimi lastnostmi lastnikov in njihovih psov smo uporabili Pearsonov koeficient korelacije, rezultati pa so prikazani v tabeli 2. Vse korelacije so statistično pomembne, čeprav večinoma nizke. Najvišje pozitivne korelacije se pojavljajo med ekstravertnostjo/odprtostjo psov ter ekstravertnostjo lastnikov, vestnostjo pripsih in lastnikih ternevroticizmom navzven pri psih in nevroticizmom pri lastnikih. Nadalje sledi visoka negativna korelacija med sprejemljivostjo lastnikov ter nevroticizmom navzven pri njihovih psih, kar je skladno z našimi pričakovanji. Sicer pa ekstravertni lastniki opisujejo svoje pse kot bolj ekstravertne, odprte in vestne. Bolj sprejemljivi lastniki opisujejo svoje pse tudi

Tabela 2. Korelacije med osebnostnimi dimenzijami lastnikov in osebnostnimi dimenzijami pri psih

\begin{tabular}{|c|c|c|c|c|}
\hline \multirow[t]{2}{*}{ Lastniki } & \multicolumn{3}{|c|}{ Nevroticizem - } & \multirow{2}{*}{$\begin{array}{c}\text { Nevroticizem - } \\
\text { navznoter }\end{array}$} \\
\hline & Energija - odprtost & navzven & Vestnost & \\
\hline Ekstravertnost &, $29^{* *}$ &,$- 26^{* *}$ &, $20^{* *}$ &,$- 20^{* *}$ \\
\hline Sprejemljivost &, $19^{* *}$ &,$- 31^{* *}$ &, $22^{* *}$ &,$- 19^{* *}$ \\
\hline Nevroticizem &,$- 12^{* *}$ &, $28^{* *}$ &,$- 23^{* *}$ &, $26^{* *}$ \\
\hline Odprtost &, $24^{* *}$ &,$- 12^{* *}$ &, $16^{* *}$ &, $11^{* *}$ \\
\hline Vestnost & $15^{* *}$ &,$- 18^{* *}$ & $29^{* *}$ &,$- 14^{* *}$ \\
\hline
\end{tabular}

${ }^{* *} p<, 01$ 


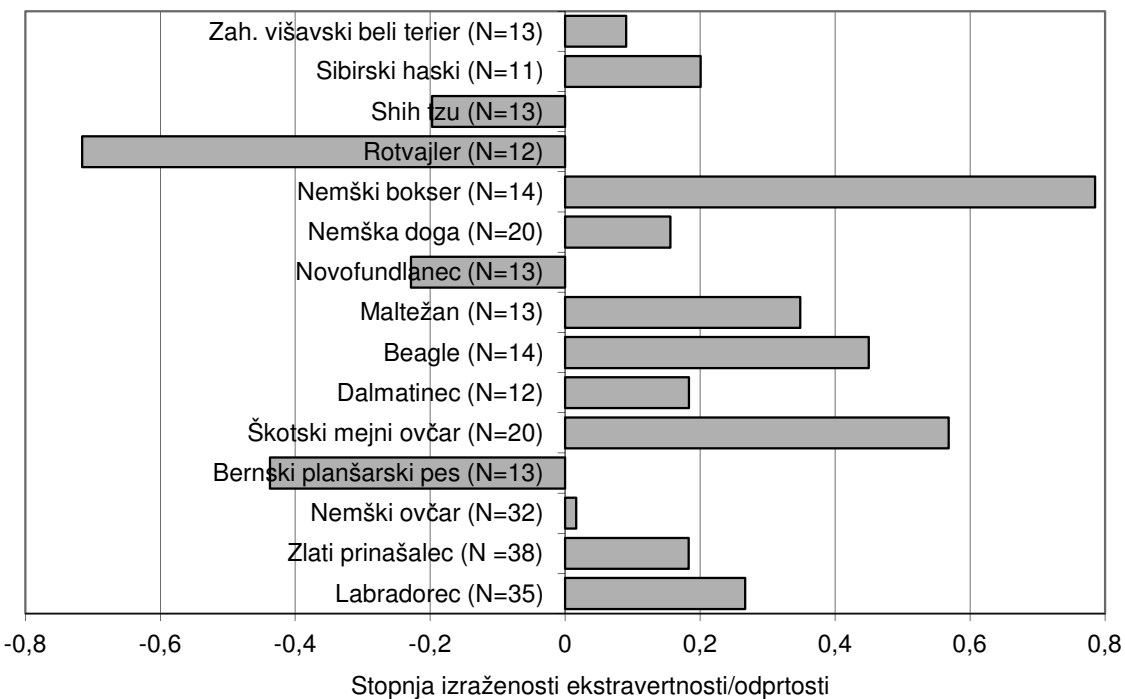

Slika 1. Povprečne vrednosti faktorja ekstravertnosti/odprtosti pri posameznih pasmah, izračunane na podlagi faktorskih točk.

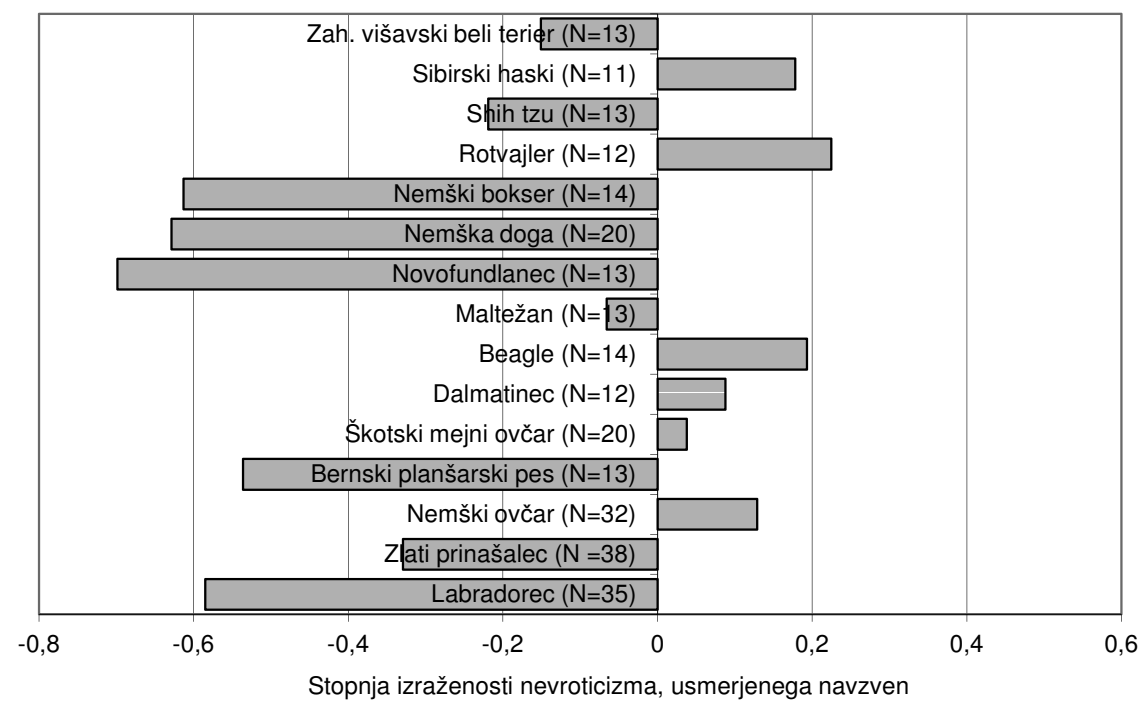

Slika 2. Povprečne vrednosti faktorja nevroticizma, usmerjenega navzven, pri posameznih pasmah, izračunane na podlagi faktorskih točk.

kot bolj ekstravertne/odprte, vestne ter manj čustveno reaktivne oz. nevrotične tako navzven kot navznoter. Bolj nevrotični lastniki opisujejo tudi svoje pse kot bolj čustveno reaktivne oz. nevrotične tako navznoter kot navzven in manj ekstravertne, odprte ter vestne. Bolj odprti lastniki svoje pse opisujejo kot bolj ekstravertne in odprte, pa tudi kot manj nevrotične navzven in bolj vestne. Zanimivo pa je, da bolj odprti lastniki svoje pse ocenjujejo kot bolj nevrotične navznoter. Vestnost lastnikov pa je negativno povezana $\mathrm{z}$ obema vidikoma nevroticizma pri psih in pozitivno $\mathrm{z}$ ekstravertnostjo/odprtostjo ter vestnostjo. Rezultati torej potrjujejo naša pričakovanja o povezanosti osebnostnih lastnosti lastnikov z osebnostnimi lastnostmi njihovih psov, čeprav je treba opozoriti, da je lahko prisotna napaka merjenja zaradi istega opazovalca in so lahko dobljene korelacije zaradi tega višje.

Nadalje so nas zanimale razlike $\mathrm{v}$ osebnostnih lastnostih med psi različnih pasem. Predhodno pa smo preverili tudi, ali obstajajo pomembne razlike med rodovniškimi in nerodovniškimi psi. Ugotovili smo, da so rodovniški psi v primerjavi z nerodovniškimi dosegli pomembno višje število točk na dimenziji ekstravertnosti/ odprtosti $(t(650)=2,881 ; p=, 017 ; d=0,17)$ ter pomembno nižje število točk na nevroticizmu, usmerjenem navzven $(t$ $(650)=-3,218 ; p=, 025 ; d=-0,24)$. Za ugotavljanje razlik med posameznimi pasmami $\mathrm{v}$ osebnostnih lastnostih smo v nadaljnjo analizo vključili le pse 15 pasem, pri katerih je bil vzorec večji od 10 , to je 278 psov. S pomočjo 


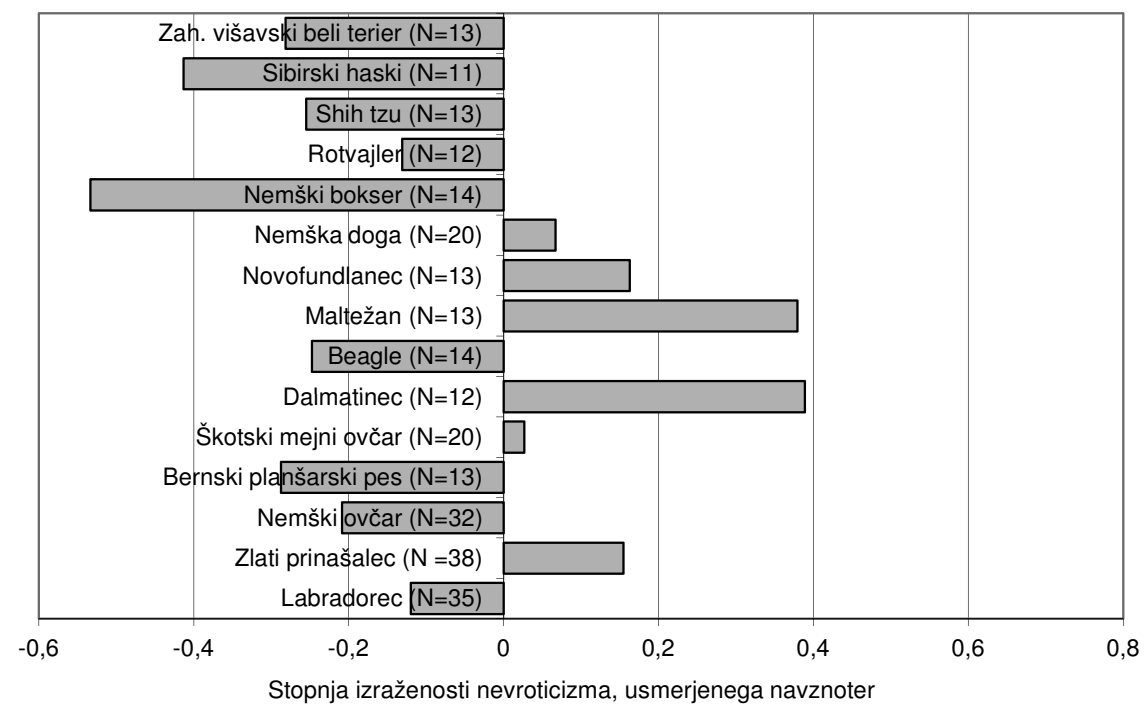

Slika 3. Povprečne vrednosti faktorja nevroticizma, usmerjenega navznoter, pri posameznih pasmah, izračunane na podlagi faktorskih točk,

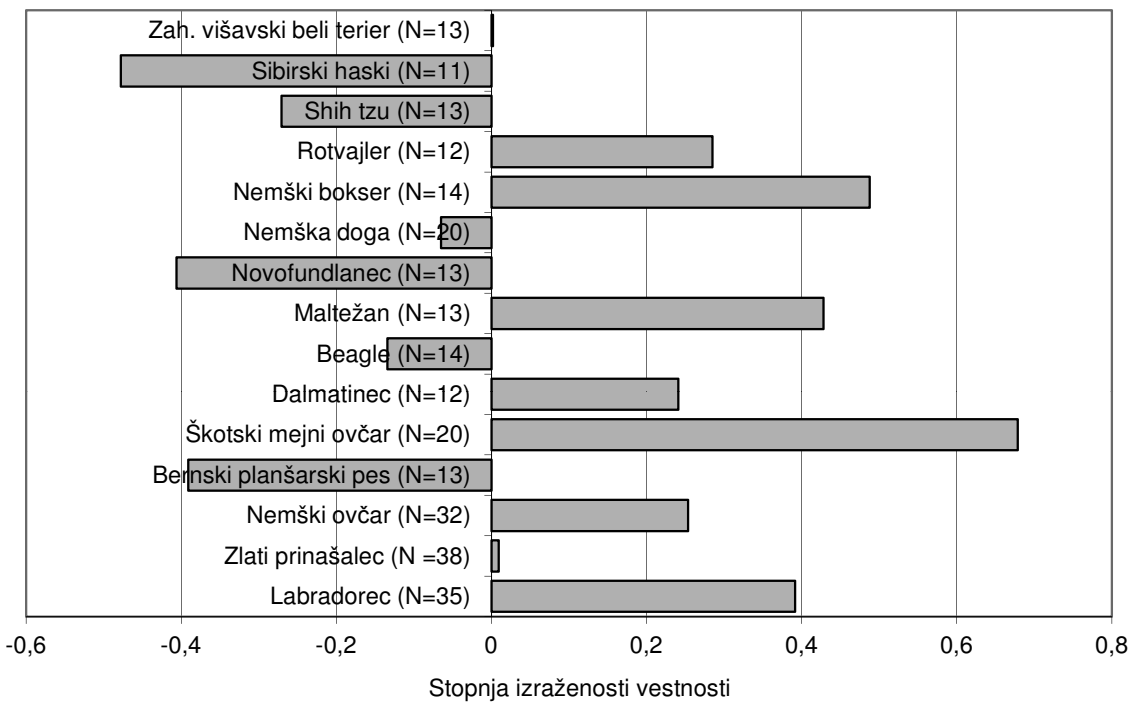

Slika 4. Povprečne vrednosti faktorja vestnosti pri posameznih pasmah, izračunane na podlagi faktorskih točk.

enosmerne analize variance za neponovljene meritve smo preverili, ali prihaja do razlik v osebnostnih lastnostih med posameznimi pasmami, pri čemer smo nadzorovali vpliv starosti psa in vpliv samoocene lastnikov za izbrano lastnost. V analizo variance smo vključili tudi spol psa in starost lastnika kot neodvisni spremenljivki, ker pa se nikjer nista izkazal kot statistično pomembni, predstavljamo rezultate brez teh dveh spremenljivk. Spola lastnika nismo vključili $\mathrm{v}$ raziskavo zaradi premajhnega števila moških lastnikov posameznih pasem.

$\mathrm{Za}$ lastnost ekstravertnost/odprtost psa rezultati kažejo, da ni pomembnih razlik med pasmami $(F(14,252)$ $\left.=1,69 ; M S E=0,18 ; p=, 058 ; \eta^{2}=0,08\right)$, je pa učinek blizu statistične pomembnosti na 5-odstotni ravni tveganja. $\mathrm{Na}$ sliki 1 lahko vidimo, da lastniki kot najbolj ekstravertne in odprte opisujejo nemške bokserje in škotske mejne ovčarje, kot najmanj ekstravertne in odprte pa rotvajlerje in bernske planšarske pse. Kot kovariat smo $\mathrm{v}$ analizo vključili tudi starost psa, ki se je izkazala za statistično pomembno: lastniki starejših psov namreč poročajo o njihovi nižji ekstravertnosti/odprtosti. Ravno tako se je izkazal pomemben učinek ekstravertnosti $(F(1,273)=$ 386,$\left.10 ; M S E=40,79 ; p=, 000 ; \eta^{2}=0,60\right)$ in odprtosti $(F(1$, $\left.273)=449.71 ; M S E=47,50 ; p=, 000 ; \eta^{2}=0,64\right)$ lastnikov na poročanje o ekstravertnosti/odprtosti njihovih psov, kar je bilo vidno že pri korelacijah (tabela 2). Bolj odprti in ekstravertni posamezniki poročajo o višji izraženosti ekstravertnosti/odprtosti pri svojih psih. 
Pri nevroticizmu, usmerjenem navzven, je prišlo do pomembnih razlik med pasmami $(F(14,252)=$ 2,37; $\left.M S E=0,51 ; p=, 004 ; \eta^{2}=0,12\right)$. Na sliki 2 lahko vidimo, da lastniki poročajo, da imajo labradorci, bernski planšarski psi, novofundlanci, nemške doge in nemški bokserji manj, rotvajlerji, sibirski haskiji in beagli pa bolj izražen navzven usmerjen nevroticizem. Starost psa se ni izkazal kot statistično pomemben kovariat $(F(1,273)=$ 2,$\left.65 ; M S E=0,57 ; p=0,105 ; \eta^{2}=0,01\right)$, medtem ko je bil nevroticizem lastnika kot kovariat statistično pomemben $\left(F(1,273)=625,70 ; M S E=135,17 ; p=, 000 ; \eta^{2}=0,71\right)$, in sicer so bolj nevroticistični posamezniki poročali o višjem nevzven usmerjenem nevroticizmu njihovih psov.

Ravno tako je prišlo do pomembnih razlik med pasmami v nevroticizmu, usmerjenem navznoter ( $F$ $\left.(14,252)=1,78 ; \quad M S E=1,07 ; p=, 004 ; \eta^{2}=0,09\right) . \mathrm{O}$ najvišjem nevroticizmu, usmerjenem navznoter, poročajo pri maltežanih in dalmatincih, o najnižjem pa pri nemških bokserjih in sibirskih haskijih (slika 3 ). Starost psa se ni izkazala kot statistično pomemben kovariat $(F(1,252)=$ 0,$\left.11 ; M S E=0,07 ; p=0,739 ; \eta^{2}<0,01\right)$, medtem ko je bil nevroticizem lastnika kot kovariat statistično pomemben $\left(F(1,252)=102,04 ; M S E=61,47 ; p<0,001 ; \eta^{2}=0,29\right)$, in sicer so bolj nevroticistični posamezniki poročali o višjem nevroticizmu, usmerjenem navznoter, torej enako kot pri nevroticizmu, usmerjenem navzven.

$\mathrm{Na}$ faktorju vestnosti je prav tako prišlo do pomembnih razlik med pasmami $(F(14,252)=2,61 ; M S E=0,26 ; p$ $\left.=0,002 ; \eta^{2}=0,13\right)$. Pri škotskih mejnih ovčarjih, nemških bokserjih, maltežanih in labradorcih je vestnost najbolj izražena, pri sibirskih haskijih, novofundlancih in bernskih planšarskih psih pa najmanj (slika 4). Vestnost lastnika je statistično pomemben faktor pri ocenjevanju vestnosti njegovega psa $(F(1,252)=2212,66 ; M S E=$ 217,84; $\left.p=0,000 ; \eta^{2}=0,90\right)$, in sicer bolj vestni lastniki svoje pse ocenjujejo kot bolj vestne.

\section{Razprava}

Rezultati, ki smo jih dobili v naši raziskavi, potrjujejo pomembno povezanost osebnostnih lastnosti lastnika $\mathrm{z}$ osebnostnimi lastnostmi njegovega psa. Rezultati so tudi pokazali nekatere razlike med pasmami $\mathrm{v}$ osebnostnih lastnostih, ki so skladne $\mathrm{z}$ opisi posameznih pasem.

Najprej nas je zanimala povezanost osebnostnih lastnosti lastnikov z osebnostnimi lastnostmi njihovih psov. Najmočnejše (negativne) povezave smo dobili med nevroticizmom navzven pri psih in sprejemljivostjo ter ekstravertnostjo njihovih lastnikov. Tudi nevroticizem, usmerjen navznoter, je pri psih negativno povezan $\mathrm{z}$ ekstravertnostjo in sprejemljivostjo lastnikov. Negativno povezanost ekstravertnosti lastnikov $z$ navzven in navznoter usmerjenim nevroticizmom pri psih lahko interpretiramo $\mathrm{v}$ smeri mirnejšega odzivanja psov na stresne situacije zaradi pogostejše vključenosti $\mathrm{v}$ različne socialne interakcije, ki je značilna za bolj ekstravertne lastnike. S pogostejšim vključevanjem psa $\mathrm{v}$ različne socialne interakcije lahko pri psu vplivamo na zmanjševanje strahu pred neznanimi ljudmi, predmeti, situacijami, kar bi lahko posledično kazalo na nižji nevroticizem. Nižji nevroticizem je značilen tudi za pse, katerih lastniki so bolj sprejemljivi in bolje sodelujejo $\mathrm{z}$ drugimi. Možno je, da so bolj sprejemljivi lastniki bolj sprejemljivo vedejo tudi do svojih psov, so do njih manj sovražni in posledično so psi manj nevroticistični.

Pozitivna povezanost med lastnikovim nevroticizmom in nevroticizmom (tako navzven kot navznoter) pri psih je primerljiva z ugotovitvami O'Farrella (1995) ter Podbersceka in Serpella (1997), ki so ugotovili več vedenjskih težav pri psih, ki so pripadali manj čustveno stabilnim lastnikom. Na lastnikovo napetost, razburljivost in stalno zaskrbljenost se psi odzivajo s plašnostjo, zadržanostjo, prepirljivostjo $\mathrm{z}$ drugimi psi in hitrim vznemirjenjem, kar so indikatorji nevroticizma.

Dimenzija ekstravertnosti/odprtosti oziroma učljivosti pri psih se pozitivno povezuje $\mathrm{z}$ ekstravertnostjo in odprtostjo njihovih lastnikov. Psi lahko zaradi lastnikovega zanimanja za različne stvari kažejo več navdušenja in samozavesti, prav tako pa imajo tudi psi lahko zaradi nižje želje lastnikov po opravljanju rutinskih stvari višjo motivacijo pri učenju. Glede na te ugotovitve so psi, katerih lastniki imajo visoko stopnjo intelektualne aktivnosti in domišljije, bolj družabni, aktivni in učljivi. Z odprtostjo lastnikov pa se negativno povezuje nevroticizem usmerjen navznoter pri psih, kar pomeni, da bolj odprti lastniki svojim psom pripisujejo manj podoživljanja dogodkov in večjo občutljivost na potrebe in čustva ljudi.

Treba je opozoriti, da je ena izmed možnih interpretacij povezanosti med lastnikovimi osebnostnimi lastnostmi in osebnostnimi lastnostmi njihovih psov tudi ta, da ocene psov odražajo zgolj zaznave njihovih lastnikov, na katere pa lahko vplivajo tudi lastnikove osebnostne lastnosti. To pomeni, da so lastniki, ki so npr. dosegli visoko število točk na osebnostni dimenziji nevroticizem, bolj občutljivi pri izražanju vedenja, povezanega $\mathrm{z}$ nevroticizmom pri njihovih psih, in so morda zato svojega psa ocenili $\mathrm{z}$ višjim številom točk od povprečja na lestvici nevroticizma (Podberscek in Gosling, 2000). Vendar lahko to razlago vsaj delno zavrnemo z ugotovitvami pretekle raziskave (Gosling idr., 2003), v kateri so z uporabo vprašalnika BFI za pse ugotovili pomembno povezanost lastnikovih ocen $\mathrm{z}$ objektivnimi ocenami vedenja psa.

Povezanost osebnostnih lastnosti med lastnikom in psom kot rezultat učinka pasjega vedenja na spremembe osebnostnih lastnosti pri lastnikih, je še manj verjetna. Večina lastnikov $\mathrm{v}$ raziskavi je bila odraslih, povprečna starost udeležencev 30,4 let, in tako lahko domnevamo, da so njihove osebnostne lastnosti relativno stabilne (Costa in McCrae, 1994). Ker je večina lastnikov, sodelujočih v raziskavi, že izkušenih lastnikov psov, je tudi malo verjetno, da bi pridobitev pasjega mladiča, ki je npr. plašen, zadržan ali agresiven, pomembno vplivala na osebnost lastnika. Za popolno izključitev te možnosti bi morali lastnike testirati pred in po pridobitvi psa 
(Podberscek in Gosling, 2000). Rezultati so zato bolj konsistentni z idejo, da se psi odzivajo na lastnikove osebnostne lastnosti, vendar so mehanizmi vzrokov in posledic še vedno nejasni. Naše ugotovitve pa ponujajo podporo tradicionalnim pogledom, da anksiozni, napeti in nevrotični lastniki lahko povzročijo višjo stopnjo razdražljivosti pri psih (Podberscek in Serpell, 1997). Ena od možnih razlag za pozitivno povezanost osebnostnih lastnosti lastnikov in njihovih psov pa bi lahko bila tudi, da lastniki izberejo psa tiste pasme, za katero so značilne podobne temperamentne lastnosti kot jih ima sam. To idejo zagovarjajo tudi Turcsan, Range, Viranyi, Miklosi in Kubinyi (2012), ki so ugotovili pomembno povezanost med osebnostjo lastnikov in osebnostjo njihovih psov, tudi če so osebnost psov ocenjevali neodvisni ocenjevalci.

Zgoraj omenjeni avtorji sicer niso proučevali razlike med pasmami v osebnostnih lastnostih, vendar, če lastniki res izberejo psa, ki jim je podoben v osebnostnih lastnostih, najbolj verjetno izbirajo glede na objavljene opise posamezne pasme in ne na podlagi opazovanja posameznega mladiča. V ozadju te razlage je torej predpostavka, da se psi različnih pasem res razlikujejo tudi $\mathrm{v}$ osebnostnih in ne samo $\mathrm{v}$ fizičnih lastnostih.

Zato nas je $\mathrm{v}$ raziskavi zanimalo tudi, ali se psi različnih pasem razlikujejo $\mathrm{v}$ osebnostnih lastnostih. $\mathrm{S}$ sistematično vzrejo naj bi rejci pri posamezni pasmi oblikovali specifičen temperament (Coren, 1996), zato smo pričakovali pomembne razlike med pasmami $\mathrm{v}$ osebnostnih lastnostih. Najprej smo preverili razlike med rodovniškimi in nerodovniškimi psi. Ugotovili smo, da imajo psi z rodovnikom $\mathrm{v}$ primerjavi z nerodovniškimi psi pomembno bolj izraženo dimenzijo ekstravertnosti/ odprtosti ter manj izražen nevroticizem navzven. Rodovniške pse torej njihovi lastniki opisujejo kot take, ki raje sodelujejo z ljudmi, ki so bolj aktivni ter manj razdražljivi kot nerodovniški psi. Razliko med rodovniškimi in nerodovniškimi psi lahko povežemo $\mathrm{z}$ načrtovanimi paritvami pri rodovniški vzreji, kjer lastniki pse za nadaljnjo vzrejo selekcionirajo tako glede na zunanji videz psa kot tudi glede na osebnostne lastnosti. Vzreja naj bi namreč potekala tudi v smeri odprave neželenega vedenja oziroma neželenih osebnostnih lastnosti, med katere sodi med drugim tudi povečana čustvena reaktivnost (Coren, 1996). Vzrejno prepoved namreč dobijo tudi psi, ki karakterno ne ustrezajo pasemskemu standardu in pri katerih je izražena izrazita plahost, nemirnost ali popadljivost (SKVPM, 2005).

Zaradi selektivne vzreje se današnji psi izredno razlikujejo med seboj po telesnih značilnostih, predvidoma pa tudi po nekaterih vedenjskih karakteristikah (Lay in Bennett, 2007). Zato smo preverili razlike med pasmami $\mathrm{v}$ izraženosti posameznih osebnostnih lastnosti med različnimi pasmami. V analizo smo vključili 15 pasem, za katere smo imeli dovolj velik vzorec. Analiza variance je pokazala pomembne razlike med pasmami $v$ treh od štirih proučevanih osebnostnih lastnostih, čeprav razlike niso velike.
Med izbranimi pasmami ni prišlo do pomembnih razlik samo $\mathrm{v}$ dimenziji ekstravertnost/odprtost. Sicer lahko prav za dimenzijo ekstravertnosti/odprtosti dobimo največ opisov temperamenta za posamezno pasmo, ker gre verjetno za najbolj vidno in hkrati najbolj zaželeno lastnost pri psih (AKC Recognized Breeds, 2013; Breed Information Centre, 2013). Kljub temu, da ni prišlo do statistično pomembnih razlik med petnajst pasmami, bi vseeno izpostavili po dve pasmi, ki imata najbolj oz. najmanj izraženo ekstravertnost/introvertnost. Za nemške bokserje in škotske mejne ovčarje naj bi bila v primerjavi z bernskimi planšarskimi psi in rotvajlerji značilna visoka stopnja energičnosti in iznajdljivosti (AKC Recognized Breeds, 2013; Breed Information Centre, 2013), kar je V skladu z našimi rezultati. Razlike med posameznimi pasmami bi lahko izvirale iz prvotne funkcije, ki so jo psi omenjenih pasem opravljali. Po prvotni funkciji so bili namreč tako rotvajlerji kot tudi bernski planšarski psi vprežni psi (Hegewald- Kawich, 2007), pri katerih je potrebna predvsem visoka stopnja fizične moči. Pri mejnih škotskih ovčarjih, ki so jih prvotno uporabljali za pašo ovac in pri nemških boksarjih, ki so ji uporabljali pri lovu na divje prašiče in medvede (Hegewald- Kawich, 2007), pa je bilo potrebno hitro odzivanje in visoka stopnja energije. Tudi danes se škotske mejne ovčarje in nemške boksarje $\mathrm{v}$ primerjavi $\mathrm{z}$ rotvajlerji in bernskimi planšarskimi psi pogosteje uporablja $\mathrm{v}$ različnih pasjih športih (npr. agility), kjer je potrebno veliko gibanja in pripravljenosti za učenje novih stvari (AKC Recognized Breeds, 2013; Breed Information Centre, 2013).

Do pomembnih razlik med pasmami je prišlo pri nevroticizmu, usmerjenem navzven. Najnižji nevroticizem, usmerjen navzven, naj bi bil značilen za novofundlance, najbolj izražen pa naj bi bil pri rotvajlerjih. Pri opisih temperamenta posameznih pasem (AKC Recognized Breeds, 2013; Breed Information Centre, 2013) ponavadi prevladujejo opisi, vezani na aktivnost, delavnost, družabnost in odprtost - sposobnost učenja, precej manj oz. praktično pa ni opisov, ki bi se nanašali na vidike nevroticizma. Problematično je tudi, da je večina pasem opisanih glede na izraženost pozitivnega pola posamezne lastnosti, če pa je za posamezno pasmo značilen bolj negativen pol te lastnosti, to ponavadi $\mathrm{V}$ opisih ni omenjeno, zato težko interpretiramo dobljene rezultate glede na skladnost $\mathrm{z}$ opisi posameznih pasem. Kakorkoli, za rotvajlerje lahko najdemo opise, da so lahko problematični, kadar so razburjeni in da to razburjenost tudi pokažejo navzven (Breed Information Centre, 2013), kar vsekakor ne drži za novofundlance, pri katerih opisi kažejo na dobrovoljnost in mirnost temperamenta (AKC Recognized Breeds, 2013; Breed Information Centre, 2013). Zaključimo lahko, da so opisi lastnikov glede izraženosti nevroticizma, usmerjenega navzven, skladni $\mathrm{z}$ opisi temperamenta teh dveh pasem.

Kar se tiče usmerjenosti nevroticizma navznoter, je še težje dobiti opise za posamezne pasme. Naši rezultati kažejo, da naj bi bil najvišji nevroticizem, usmerjen 
navznoter, prisoten pri maltežanih in dalmatincih, najnižji pa pri nemških bokserjih in sibirskih haskijih. Posredno bi lahko sklepali o nižjem nevroticizmu, ki je usmerjen navznoter, pri psih, ki jih opisujejo kot vesele, ki se radi zabavajo, kar naj bi veljalo maltežane in dalmatince (AKC Recognized Breeds, 2013; Breed Information Centre, 2013), za katere po drugi strani lastniki menijo, da imajo visok nevroticizem, usmerjen navznoter. Nevroticizem, ki je usmerjen navznoter, je z vidika zunanjega opazovalca težko zaznati in vprašanje je, v kolikšni meri gre res zgolj za projekcijo lastnih občutij lastnika v psa, v kolikšni meri pa res lahko govorimo o tej lastnosti pri psih. Zato verjetno tudi ni opisov te lastnosti v opisih, ki jih podajajo vzreditelji. Za rezultate razlik med pasmami $\mathrm{v}$ nevroticizmu, usmerjen navznoter, torej ne moremo reči, ali so skladni z opisi vzrediteljev, ker teh opisov ni.

Na faktorju vestnosti je prav tako prišlo do pomembnih razlik med pasmami. Pri škotskih mejnih ovčarjih je glede na opise lastnikov vestnost najbolj izražena, pri sibirskih haskijih pa najmanj. Če pogledamo opise pasem, naj bi bila za škotske mejne ovčarje res značilna vztrajnost, delavnost, ubogljivost in potrpežljivost (AKC Recognized Breeds, 2013; Breed Information Centre, 2013), kar je povsem skladno $\mathrm{z}$ našimi rezultati o nadpovprečni vestnosti te pasme. Po drugi strani vzreditelji (AKC Recognized Breeds, 2013; Breed Information Centre, 2013) opisujejo sibirske haskije kot pse, ki imajo lahko problematičen karakter in zato potrebujejo skrbno vzgojo, iz česar lahko posredno sklepamo na nižjo ubogljivost, ki pa ni glavna ali edina komponenta vestnosti, zato spet težko ocenimo, ali so rezultati skladni s pričakovanji.

Glede razlik med pasmami v osebnostnih lastnostih lahko zaključimo, da so naši rezultati deloma skladni z opisi, ki jih navajajo vzreditelji, deloma pa primerjav ne moremo narediti, ker so opisi temperamenta posameznih pasem zelo skromni in nesistematični (AKC Recognized Breeds, 2013; Breed Information Centre, 2013). Ker je bilo pri določenih pasmah število psov majhno (okoli 10), bi bilo potrebno za bolj jasne določitve osebnostnih razlik med posameznimi pasmami $\mathrm{v}$ nadaljnjih raziskavah preučiti večje število udeležencev posamezne pasme. Priporočljivo bi bilo preverjati tudi osebnostne razlike med psi znotraj posameznih pasem in med pasemskimi skupinami, kot jih določa Mednarodna kinološka zveza (FCI). Pasme so v posamezne skupine razvrščene glede na namen uporabe, npr. lovski psi, ovčarski in pastirski psi, itd. Nekatere pasme znotraj posamezne skupine imajo morda zaradi namena uporabe ter vzreje za določene namene, npr. za lov, podobne lastnosti, kar je lahko vzrok za majhne razlike med pasmami v naši raziskavi. Posamezne pasme, ki smo jih primerjali med seboj namreč pripadajo isti pasemski skupini, vendar zaradi premajhnega števila psov določenih pasem, le teh nismo mogli razvrstiti $\mathrm{v}$ pasemske skupine, kot jih določa Mednarodna kinološka zveza.

Majhne razlike med pasmami $\mathrm{v}$ osebnostnih lastnostih pa so lahko tudi posledica preverjanja le štirih splošnih osebnostnih dimenzij oziroma dimenzij, katere se upoštevajo pri selektivni vzreji vseh pasem. Pri psih namreč ni zaželena visoka izraženost čustvene reaktivnosti, prav tako pa je zaradi tesne povezanosti psa s človekom bolj zaželena dimenzija sprejemljivosti in ekstravertnosti, zaradi česar morda večina vzrediteljev teži k odpravljanju ali povečevanju določenih lastnosti pri psih, ki predstavljajo le družabnika človeku (Serpell in Jagoe, 1995). Za ugotavljanje razlik med posameznimi pasmami bi bilo $\mathrm{v}$ nadaljnjih raziskavah torej dobro preverjati bolj specifične oblike vedenja, na primer dominantno vedenje, usmerjeno na drugega psa.

$\mathrm{V}$ raziskavi smo ugotovili, da se večina osebnostnih lastnosti lastnika pomembno povezuje $\mathrm{z}$ osebnostnimi lastnostmi njegovega psa ter pojasnili, zakaj je interpretacija $\mathrm{v}$ smeri lastnikovega vpliva na vedenje psa verjetna. Čeprav se pogosto namiguje, da je pripisovanje odgovornosti lastnikom za problematično vedenje živali neprimerno, je smiselno upoštevati vsak faktor, ki poveča verjetnost razvoja težav pri psih (Podberscek in Serpell, 1997). Zaradi velikega poudarjanja genetskih dejavnikov na oblikovanje osebnosti pri psih, smo preverjali tudi obstoj razlik na posameznih osebnostnih dimenzijah glede na pasmo. $\mathrm{V}$ naši raziskavi smo ugotovili, da obstajajo nekatere razlike med pasmami, ki so skladne $\mathrm{z}$ opisi osebnostnih značilnosti posameznih pasem (AKC Recognized Breeds, 2013; Breed Information Centre, 2013), zato lahko iz dobljenih rezultatov zaključimo, da $\mathrm{k}$ oblikovanju osebnostnih lastnosti psov vsaj deloma pripomorejo tudi genetski dejavniki, vendar je naša interpretacija zaradi načina pridobivanja podatkov zgolj hipotetična. Pomanjkljivost naše raziskave je tudi v tem, da so lastniki ocenjevali sebe in svoje pse, kar pomeni, da je lahko prišlo do napake istega opazovalca in so zato povezave, ki smo jih dobili v naši raziskavi, višje kot so $\mathrm{v}$ resnici. Kljub temu, da predhodne raziskave kažejo, da so lastniki dobri ocenjevalci lastnosti svojega psa (Gosling idr., 2003), bi veliko pridobili, če bi namesto samoocenjavanja osebnost lastnikov uporabili ocene s strani pomembnih drugih, kar je verjetno precej lažje izvedljivo kot če osebnost psov ne bi ocenjevali njihovi lastniki. Pomanjkljivost raziskave predstavlja uporaba izbranega vprašalnika za ocenjevanje osebnostnih lastnostih pri psih. Ker je po našem vedenju trenutno edini, ki omogoča ocenjevanje različnih vidikov osebnosti psa in ne zgolj nekaterih specifičnih vedenj psa, smo ga uporabili kljub pomanjkljivim informacijam o njegovi veljavnosti in nizki zanesljivosti nekaterih komponent.

Prav tako kot na področju človekove razvojne psihologije, se bodo verjetno tudi na področju pasjega vedenja nasprotujoča mnenja o vzrokih vedenjskih težav zbližala na sredini, in sicer, da je vedenje psa rezultat trajne interakcije med genetskimi vplivi in fizičnim ter socialnim okoljem, v katerem se pes razvija (Podberscek in Serpell, 1997). Naši rezultati so skladni s temi pogledi, saj kažejo, da so osebnostne lastnosti psov povezane tako $\mathrm{z}$ osebnostjo lastnika kot tudi s selektivno vzrejo. Naša 
raziskava pa nakazuje tudi potrebo po enotni taksonomiji osebnostnih lastnosti pri psih, saj so opisi temperamenta posameznih pasem večinoma zelo površni, subjektivni in ne pokrivajo vseh specifičnih vedenjskih značilnosti posameznih pasem.

\section{Literatura}

AKC Recognized Breeds. (2013). American Kennel Club. Pridobljeno s spletne strani http://www.akc. org/breeds/breeds_a.cfm.

Avsec, A. (2007). Pet velikih faktorjev osebnosti. V A. Avsec (ur.), Psihodiagnostika osebnosti (str. 121-152). Ljubljana: Filozofska fakulteta Univerze v Ljubljani.

Blood, D. C. in Studdert, V. P. (1988). Bailliere's comprehensive veterinary dictionary. London: Bailliere Tindall.

Breed Information Centre (2013). The Kennel Club. Pridobljeno s spletne strani http://www.the-kennelclub.org.uk/services/public/breeds/Default.aspx

Coren, S. (1996). Inteligenca psov: Pasja zavest in sposobnost mišljenja [The intelligence of dogs]. Ljubljana, Slovenija: Dedal.

Costa, P. T. Jr. in McCrae, R. R. (1994). Set like plaster? Evidence for the stability of adult personality. V T. F. Heatherton in J. L. Weinberger (ur.), Can Personality Change? (str. 21-40). Washington, DC, ZDA: American Psychological Association.

Gosling, S. D. (1998). Personality dimensions in spotted hyenas (Crocuta crocuta). Journal of Comparative Psychology, 112, 107-118.

Gosling, S. D. (2001). From mice to men: What can we learn about personality from animal research. Psychological Bulletin, 127, 45-86.

Gosling, S. D., Kwan, V. S. Y. in John, O. P. (2003). A dog's got personality: A cross- species comparative approach to personality judgements in dogs and humans. Journal of Personality and Social Psychology, 85,1161-1169.

Gosling, S. D. in Vazire, S. (2002). Are we barking up the tree? Evaluating a comparative approach to personality. Journal of Research in Personality, 36, 607-614.

Hegewald- Kawich, H. (2007). Pasme psov od A do Ž. Kranj: ADOZ tisk.

Jagoe, A. in Serpell, J. (1996). Owner characteristics and interactions and the prevalence of canine behaviour problems. Applied Animal Behaviour Science, 47, 31-42.

John, O. P., Donahue, E. M. in Kentle, R. L. (1991). The Big Five Inventory-Versions $4 a$ and 54. Berkeley, CA, ZDA: University of California, Berkeley, Institute of Personality and Social Research.

Jones, A. C. in Gosling, S. D.(2005). Temperament and personality in dogs (Canis familiaris): A review and evaluation of past research. Applied Animal Behaviour Science, 95, 1-53.
Kenrick, D. T., in Funder, D. C. (1988). Profiting from controversy: Lessons from the person- situation debate. American Psychologist, 43, 23-34.

Kenttamies, H., Valberg- Nordum, N., Brenoe, U. T., Smeds, K., Johannessen, K. R. in Bakken, M. (2002). Selection for more confident foxes in Finland and Norway: Heritability and selection response for confident behaviour in blue foxes (Alopex lagopus). Applied Animal Behaviour Science, 78, 67-82.

Kubinyi, E., Turcsán, B. in Miklósi, Á. (2009). Dog and owner demographic characteristics and dog personality trait associations. Behavioural Processes, 81, 392-401.

Lay, J. M. in Bennett, P. C.(2007). Understanding personality by understanding companion dogs. Anthrozoos, 20, 113-124.

Ley, J., Bennett, P. in Coleman, G. (2008). Personality dimensions that emerge in companion canines. Applied Animal Behaviour Science, 110, 305-317.

Lindsey, S. R., (2000). Handbook of applied dog behaiour and training: Vol 1. Adaptation and learning. Ames: Iowa State University Press.

Mirkó, E., Kubinyi, E., Gácsi, M. in Miklósi, Á. (2012). Preliminary analysis of an adjective-based dog personality questionnaire developed to measure some aspects of personality in the domestic dog (Canis familiaris). Applied Animal Behaviour Science, 138, 88-98.

Mugford, R. A. (1995). Canine behavioural therapy. V J. Serpell (ur.), The domestic dog: Its evolution, behaviour, and interactions with people (str. 139152). Cambrige: Cambrige University Press.

O'Farrell, V. (1995) . Effects of owner personality and attitudes on dog behaviour. V J. Serpell (ur.), The domestic dog: Its evolution, behaviour, and interactions with people (str. 153-158). Cambrige: Cambrige University Press.

Podberscek, A. L. in Gosling, S. D. (2000). Personality research on pets and their owners: Conceptual issues and review. V A. L. Podberscek (ur.), Companion animals and us: Exploring the relationships between people and pets.(str. 143-167). Cambridge, Velika Britanija: Cambridge University Press.

Podberscek A. L., in Serpell, J. A. (1997). Aggressive behaviour in English cocker spaniels and the personality of their owners. The Veterinary Record, 141, 73-76.

SKVPM- Slovenski klub za velike pasme in molose. (18.2.2005). Pravilnik o vzreji. Pridobljeno 20.2.2013 s spletne strani http://www.skvpm-klub.si/pravilnik. html.

Serpell, J. (1995). The domestic dog: Its evolution, behaviour, and interactions with people. Cambridge: Cambridge University Press.

Serpell, J. in Jagoe, J. A. (1995). Early experience and the development of behaviour. V J. Serpell (ur.), The domestic dog: Its evolution, behaviour, and interactions with people (str. 79-102). Cambridge: Cambridge University Press. 
Svartberg, K. (2002). Shyness-boldness predicts performance in working dogs. Applied Animal Behaviour Science, 79, 157-174.

Svartberg, K. (2006). Breed-typical behaviour in dogs: Historical remnants or recent constructs? Applied Animal Behaviour Science, 96, 293-313.

Trut, L. N., Plyusnina, I. Z. in Oskina, I. (2004). An experiment on fox domestication and debatable issues of evolution of the dog. Russian Journal of Genetics. 40, 644-655.

Turcsan, B., Range, F., Viranyi, Z., Miklosi, A. in Kubinyi, E. (2012). Birds of a feather flock together? Perceived personality matching in owner-dog dyads. Applied Animal Behaviour Science, 140, 154-160. 